
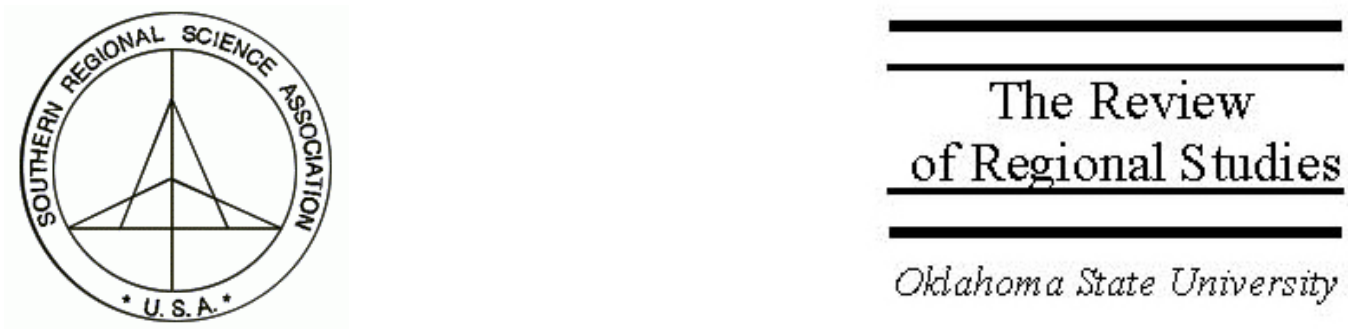

Oklahoma State University

\title{
Southern Regional Science in Interstitial Space
}

\author{
Fellows Address \\ Southern Regional Science Association \\ April 2004 \\ Mark S. Henry \\ Professor, Department of Applied Economics and Statistics, \\ Barre 254, Clemson University, Clemson, South Carolina 2963- 0313 \\ e-mail:mhenry@Clemson.edu
}

\begin{abstract}
Regional science has a variety of characteristics that distinguish it from its sister social sciences: it works the boundaries of economics, geography, planning studies, and sociology; space is its focus; spatial dependence is a core concern; comparative advantage remains a key concept for understanding how space will develop. Facing new and old challenges from global competition, lagging regions of the U.S., and especially in the rural South, will need new ideas from regional science on how to fit into the emerging economy in ways that promote higher incomes across all deciles of the income distribution.
\end{abstract}

Keywords: Regional Science; Spatial dependence; Lagging regions

JEL classification: R10 


\section{INTRODUCTION}

First, let me express appreciation to the Southern Regional Science Association for this honor. I have participated in every SRSA meeting since giving a paper at the sessions in Nashville in the spring of 1979. I remember that Bill Miernyk was there and actually said something nice about the paper - much unexpected, and I am sure to the relief of Jim Hite at Clemson University where I had just been hired. Jim was then the Secretary-Treasurer of the SRSA - the person who kept the association going from year to year. Little did I know that Jim and the SRSA would soon give me the opportunity to serve the SRSA in that role for the next decade or so. This, of course, was in the days before email and the Internet, so phone tag was a serious game when organizing anything. In retrospect, those were heady days for a young regional science type interacting with the likes of Bill Miernyk, Bill Schaffer, Shirley Weiss, Barry Moriarty, Niles Hansen, Lowell Ashby, Jack Cumberland, and the other early stalwarts of the SRSA. I thank them and Jim Hite for trusting that the SRSA would not fade away in my hands.

Second, while this honor is in large part due to this opportunity to serve the SRSA, the real reward to me has been the exposure to new ideas in a collegial environment that has characterized the past 25 years of the SRSA meetings. SRSA scholars also have a tradition of working with policy makers that gives this organization a unique flavor. For example, Bill Miernyk was a frequent advisor to governors and legislators in West Virginia. The Regional Research Institute at WVU was formed, in part, to connect regional science scholars with policy makers. It has evolved under the creative and energetic minds of SRSA scholars Andy Isserman, Scott Loveridge, and now Randy Jackson to become a leading academic center for regional science. The Web Book of Regional Science, initially launched by Scott, is probably the single most important beacon to students and scholars around the world of what regional science is all about. For example, the Geography Department at the University of Paris says this about it.

An extraordinary site assembled by American faculty who are clearly attached to the notion of public service. The Web Book of Regional Science (geography, economics, sociology) is comprised of about twenty regional science contributions covering diverse subjects such as regional networks, land use, migration, regional specialization. . . . Each book is completely accessible by Internet and includes a bibliography as well as links to other sites. In sum, it is a veritable gold mine to deepen understanding of regional science (http://www.rri.wvu.edu/regscweb.htm).

Like the authors of chapters in the Web Book of Regional Science, my thesis today is that southern regional science scholars (some of whom are Web Book authors) have been demonstrating that regional science adds value to other approaches to social and economic problems for over four decades. Not too fat on place details or too thin in providing a conceptual model of behavior. Often, this approach developed because policy makers needed solutions. For example, like Bill Miernyk in West Virginia, Jim Hite worked with legislators in South Carolina for over two decades and was effective in 
getting them to listen by translating academic work into policy briefs that made sense to them - they conveyed a solution to a legislative problem.

Despite this legacy of policy-focused work by many scholars of the SRSA, there remains that nagging question, "Exactly what is regional science?” One answer is simply to define regional science as a gathering place for scholars to interact when, in Krugman slang, they are "Lost in Space - the Final Frontier." Alternatively one can point to some characterizations of the work of regional scientists that help to define its identity.

First, we work in interstitial space.

An interstitial space is space that is given an active definition, quite different than the space that we normally encounter in the real world, space that exists passively and is then "filled" with content. Interstitial space is content itself and not just a content carrier (2000 Rabid Architecture \& Design VR Research, http://www.art.abk-stuttgart.de/sb/).

Like this architect's view of interstitial space, in regional science we contend that space matters - and not just as a transportation cost nuisance in economic models - but that it has content itself or "essence" in the words of Walter Isard. Still, given budget realities at universities and in government agencies, regional science scholars seek affirmation from a home discipline - economics, geography, sociology, etc. For example, in the recent Golden Anniversary issue of the Papers in Regional Science, Chatterji and others maintain that the path breaking works in regional science by Isard and Alonso were attempts to gain acceptance of space by economists as a mainstream concern.

Abstracting regional science journals first in the Journal of Economic Abstracts in 1968 and then in the Journal of Economic Literature, as well as establishment of a geography and regional science section by the National Science Foundation are noted by others as important signals of acceptance of regional science as a "sub-discipline" (Schaefer 2004, p. 82). More recently, the Fujta, Krugman, and Venables (1999) models for explaining spatial structure and spatial dynamics have attracted the attention of economists and geographers, while Fujita-Thisse's Economics of Agglomeration suggests that regional science is becoming more firmly embedded in "mainstream" economics.

Of course, Krugman et al. also ignited concerns that the "New Economic Geography" (NEG) is not economic geography but geographical economics - that is, there is no sense of place in those phase diagrams or in the Dixit-Stiglitz model. Some argue that the NEG is exactly what is needed at the abstract level to understand what regional "essence" means when explaining why regions prosper or decline, while others maintain that the NEG is much too "thin" to incorporate the nuances of places that matter to the development of a region. Alternatively, Glaeser and Kohlhase (2004, p. 199) argue that the NEG's foundation of "fixed cost technologies with substantial transportation costs" are out of touch with twenty-first century realities and focus should be on the role of "agglomeration effects and the ease of access to other people - not transport costs of 
goods.” Kilkenny (1998) earlier offered her own views on how the NEG can be modified to incorporate more compelling depictions of how regional and rural economies work.

While geographers, economists, and others often have tunnel vision on approaches to the problem of "how space matters," regional science fills the interstitial space between the boundaries of these social sciences. On an organizational level, it provides the means - meetings, journals, workshops, and a focus on space - to engage planners, geographers, sociologists, and economists to move beyond what each discipline alone offers. Regional scientists like to work the boundaries and pull together ideas from "home disciplines" in ways that add value to the thinking in those disciplines, that is, to fill the interstitial space between the ideas offered by social scientists investigating spatial problems.

A second fundamental characteristic of regional science is that it provides a focus on how space matters. In first courses in economics, you learn that economic man's behavior is rooted in fundamental truths: more is preferred to less, etc. Alchian and Allen (1964, p. 22-23) explain how these postulates form hypotheses needed to explore the behavior of economic man. In contrast, regional science seems to stake its claim as a science on Isard's (1956) belief that "the region has its own 'essence' which can be grasped in full only by tools, hypotheses, models and data processing techniques specifically designed for regional analysis."

While Isard (1975, p. 5) provides a list of 13 definitions of regional science in his Introduction to Regional Science, each is a vector of interests associated with regions or space. This list is so comprehensive and non-exclusionary that it may appear that only space matters in solving social and economic problems. This may be as good as it gets in establishing an identity for regional science, but it strikes me as an extreme view of the role of space in the social sciences - something like the "spaceless economy" view of most economists.

\section{FUNDAMENTAL OBSERVATIONS ON HOW SPACE MATTERS}

Consider some observations of how space matters that are analogous to those in economics. First, in economics (from Alchian and Allen) "the unit of analysis is the individual" while in regional science, one can argue that the unit of analysis is the region that is formed by the actions of individual agents. Second, in economics, "no man can see the future perfectly" (from Alchian and Allen) while in regional science no region is independent of the acts of other regions.

Consider a few examples. First, spatial interaction models, especially the recent discovery of gravity models by trade economists, all employ methods to recognize spatial dependence - in a broad sense. From gravity models to interregional input-output models and the core-periphery of the NEG, regional interdependence is a fundamental force that attracts the attention of regional scientists. A recent policy example is the effort of the Department of Homeland Security (DHS) to build state-to-state interregional IO models so they can track the consequences of a shock in one state on all others. Presumably, the 
rationale for finally achieving what my mentor and advisor, Jarvin Emerson, once called the holy grail of regional IO modelers is the policy makers' perception that contingency plans should and can be developed for states to avoid disasters in one state cascading across other states. While this initiative is no doubt welcomed by underemployed regional scientists, it is far more important as a signal of the importance of the interdependence of regions - a key observation that helps to define the work of regional science.

Another example of the need to focus on spatial interaction was revealed at a recent conference organized by the Rural Policy Research Institute (RUPRI) on the role of place in understanding rural poverty. Bruce Katz, the Director of the Brookings Center for Urban and Metropolitan Policy, emphasized the role of space in understanding interactions between the urban core, suburbs, and proximate rural areas to do both academic and policy analysis of urban problems - for example, urban sprawl and "smart growth policy." To regional scientists this notion of a functional economic region is obvious, but at this recent conference on rural poverty the need to look at rural/urban interactions was seen as a novel insight. These policy wonks and academics were acknowledging what regional science has at its core - that space and place matter in policy formation, as Tom Johnson (2002) emphasized in his Fellows address to the SRSA.

On stochastic modeling frontiers, spatial dependence in econometric models has been given formal treatment by Anselin (1988), LeSage (1999) and others who are either trained in regional science and/or are participants at regional science meetings. A focus on how space can affect econometric results is an important outcome established by scholars with an interest in regional science. The continuing refinement of related software by these analysts has broadened the base of applications across all the social sciences. This initial focus on spatial dimensions of the problem by regional scientists has had spillover effects in sociology, economics, planning studies, and geography. Regional scientists provided value and content to these disciplines.

With a focus on regions as observations and recognition that regions exhibit spatial dependency, let me add one additional observation that represents an important challenge to regional scientists. Again contrasting this observation with an Alchian-Allen (1964) postulate in economics that "each person seeks a multitude of goods," one can argue that a regional science postulate is that each region seeks higher levels of well being for (at least some of) its people. While in one sense this states the obvious, social structure can be a critical, but often underappreciated, force in shaping how a region develops.

Since we are meeting in New Orleans, let me pick on it and proximate rural areas of the Mississippi delta region to illustrate what I mean. New Orleans was the wealthiest southern city in the early history of the United States (Barry 1997). Now, if you take the St. Charles Avenue streetcar from Canal Street to the Garden District, you will see beautiful live oaks lining the front yards of handsome homes of the well-heeled citizens of this city. Once you get off the streetcar and walk not too many blocks perpendicular to St. 
Charles, you encounter the other New Orleans. These are the public projects and shotgun shacks in spaces that were the quarters, first for slaves of the nearby plantation owners, and now subsistence housing for low-income families. This spatial pattern of housing with rich and poor so near - is one example of spatial development associated with enduring path dependence formed initially by "historical accident."

The propensity to perpetuate this spatial path dependence is illustrated by John Barry's (1997) powerful depiction in A Rising Tide of how the great Mississippi flood of 1927 wreaked havoc on people and property up and down the Mississippi River. However, New Orleans was spared. According to Barry, the local bankers' cartel was able to convince the government to blast holes in the levee system downstream from New Orleans - causing severe flooding in "low-income" areas with the city's and bankers' promise (never kept) to fully reimburse property owners in St. Bernard and Plaquemines parishes for their losses. Ironically, it was not needed to save New Orleans as breaks further downstream relieved the pressure on the New Orleans section of the river, but it intensified social and economic forces that pushed New Orleans to the back burner as a growth center of the South. Barry concludes:

... New Orleans had been exclusive from the first. When the U.S. initially gained sovereignty over the city, the existing French and Spanish elite had mocked the Americans, who in turn created their own institutions, including the Carnival krewes. Over the next century, the Americans with their money took over their pretensions. But before the flood, New Orleans had at least accepted transfusions of fresh blood. After the flood the city grew ever more insular. ... [The ] social system excludes executives recently transferred to New Orleans and discourages their participation in community issues .... . A narrow circle of wealth holders ... represent a closed society whose aims are to preserve their wealth rather than incur new risks in an effort to expand it. ... And so the city decayed. Before the flood, New Orleans had vastly more economic activity than any city in the South. Decades later, while in the newest New South such cities as Charlotte and Miami - not to mention Atlanta, Dallas and Houston - thrived and grew, New Orleans fell far behind its old competitors, and banks even in Memphis now dwarf those in New Orleans. . . . New Orleans had become even more ingrown. . . . Only the port. . . remained vital. The city had become a place for tourists. . . . (Barry 1997, pp. 410-411).

A physical shock to a region had profound social and economic consequences for spatial development of the South. While those in power were able to save their New Orleans and their businesses from the devastating flood of 1927, proximate rural agricultural areas paid the price. Each region seeks higher levels of well being for (at least some of) its people.

The legacy of lagging rural areas remains throughout the South, as Ed Malecki (1995), David Barkley (1998), and Robert Gibbs (2003) each lamented in their Presidential Addresses to the SRSA over the past decade or so. This also implies a failure by regional scientists to understand what can be done to promote more effective use of the resources of lagging regions of the U.S. - whether they are in the urban core of 
New Orleans or rural South. I think this is because the role of power in regional development has not been given enough attention. Hopefully, renewed interest in social and political capital will remedy this neglect and yield better insights into how academic work can be more effective in promoting programs and policies to improve the wellbeing of the lower deciles of the income distribution and not just the mean level of per capita income. ${ }^{1}$

Indeed, some politicians seem to recognize the need for a rural-urban balance as the national economy expands:

Rural incomes have grown too slowly, the task of increasing employment and improving social security is arduous, development in different regions of the country is not balanced. The income gap is too wide among some members of society and pressure on resources and the environment is mounting.

And this leader "urged officials to put into practice what he called a "scientific concept of development" that would balance economic growth with social progress, urban boom with rural-well being" (China's Premier Wen Jiabao as quoted in the Washington Post, 2004, p. A12). With 800 million or so rural Chinese lagging behind residents of the urban growth centers along the east coast of China, it is not surprising that a new political sense of urgency for rural development has taken hold in China.

\section{LAGGING REGIONS AND INTERSTITIAL SPACE}

Unlike China, in the United States there is little sense of urgency to address lagging rural areas. Instead, politicians fund old-fashioned subsidies to the powerful farm commodity interests and justify these market-distorting actions as necessary to support the "family farm" and rural America. To enlighten politicians and policy makers alike, regional scientists should redouble their efforts to fill the interstitial space needed to help lagging regions. Particularly in the South, finding "what we do best" is perhaps most interesting when faced with understanding how lagging rural counties in the South or the urban core can "catch up" when low-skill manufacturing jobs, and now increasingly some high-skill jobs, have migrated overseas.

Some urban areas like Fairfax County, Virginia are fighting the Bangalore challenge by opening an office in Bangalore to recruit foreign firms to Fairfax (Washington Post, 2004). But when it comes to outsourcing and rural areas of the U.S., Tom Friedman's

${ }^{1}$ South Carolina leaders increasingly recognize that cheap labor and land will not be good substitutes for human capital as it pours tax (lottery) dollars into hiring endowed chairs at state universities. However SC still ignores quality in K-12 by skimping on public school funding while, in effect, promoting dual school systems with proposals for tax credits for the middle class to send kids to private academies or with current tuition grants to cover increasing costs of attending public colleges. Again it seems that power often trumps reason in understanding the value of sustained investments in K-12 education to a broad cross section of society. 
(2004) insights drawn from another part of the world seem more appropriate. He laments the fact that the Arab world is never mentioned as a possible source for hi-tech jobs or any other jobs. In his view, this paucity of jobs breeds discontent, and in some cases radicalism and terrorism. One could ask the same question about much of the rural south and inner cities in places like New Orleans.

Microsoft, Intel, and Motorola are not seeking new locations in the rural South despite the ease of transferring information. Hansen (2000) argues that the new economy, in fact, offers many opportunities to more remote areas. Moreover, he demonstrates that knowledge spillovers are not likely to be dependent on proximity to a major metro area - the spillovers are indeed international in the space economy. But the rural South is not well positioned to take advantage of these new-economy jobs because, unlike the old product cycle spinning off low-wage, low-skill jobs to the rural South in textiles and apparel, the new product cycle spins jobs to low-wage, high-skill areas of the world. Unlike places like Bangalore, the rural South simply lacks the human capital to take advantage of these new jobs.

Even if outsourcing is globally efficient, there is the nagging issue of "transition" and the ignored spatial implications of regional winners and losers - at least in what might be a lengthy transition period. As corporate America seeks ever lower cost locations for low-skill jobs, the rural South must look elsewhere to find jobs for its region. Linking up with "regional innovation centers" (RIS) of the urban South by promoting excellence in public services and attracting residents is a theme of some (Barkley et al. 2004). But there is much work to do and it's not even clear that RIS really exist in a form that generates spillover effects from urban growth centers to proximate rural communities. This presents an opportunity for southern regional scientists to fill the interstitial space with new ideas on how these lagging areas can progress in this new environment.

On the labor supply side, Richard Florida's (2003) creative class thesis is that there is a certain kind of cultural milieu that a place needs to attract the entrepreneurial class and thus long-term growth through innovation and risk taking. This is a theme that a favorite son of the SRSA, Niles Hansen, developed long before Florida in his work on regional development in Europe. Variety and diversity may very well be the drivers of how a place will fare in the age of innovation-driven development. How communities in lagging regions of the United States can participate in this model of development is an open question but one that regional scientists are well equipped to answer.

\section{CONCLUSION}

Regional science has a variety of characteristics that distinguish it from its sister social sciences: it works the boundaries of economics, geography, planning studies, and sociology; space is its focus; spatial dependence is a core concern; comparative advantage remains a key concept for understanding how space will develop; regional variety and sense of place affect how a region will grow or decline. Facing new and old challenges from global competition, lagging regions of the U.S., and especially in the rural 
South, will need new ideas from regional science on how to fit into the emerging economy in ways that promote higher incomes across the board - not just for a powerful few. Farm subsidies and their ilk are not the answer, but solutions that draw on fundamentals of regional science can help to identify opportunities for lagging areas. Regional interdependence and the role of power will be keys to understanding how lagging areas will fare over the next decade. SRSA scholars will play an important role in developing this base of knowledge as they add value to the work of other social scientists.

Regional science needs to continue to fill interstitial gaps between the disciplinary circles or it will simply be absorbed as a minor cog in home departments - sort of a bidding away of the regional science identity so that the disciplinary circles become hexagons - and the domain of regional science vanishes. Of course, at the birthplace of regional science in the U.S., this bidding away is exactly what happened when the regional science faculties were dispersed across campus. Still regional science meetings, like this conference in New Orleans, continue to attract talented scholars. It may be that it was the sense of this place - New Orleans - that drew you to this meeting, since you could have presented your paper at the AAEA, AEA, ASA, or AAG meetings instead and you may have a second draft in mind for those disciplinary sessions. If your experiences at regional science meetings have been as invigorating as mine over the years, your second draft should benefit from the new perspectives you gain here. This is what regional scientists do. They create an interstitial social science space that has content for scholars.

\section{REFERENCES}

Alchian, A.A. and W.R. Allen, 1964. University Economics, Second Edition. Wadsworth Publishing: Belmont, CA.

Alonso, W., 1964. Location and Land Use. Harvard University Press: Cambridge, MA.

Anselin L., 1988. Spatial Econometrics: Methods and Models. Kluwer Academic Publishers: Dordrect.

Barkley, D.L., 1998. "Communities Left Behind: Can Nonviable Places Become Smart?” Review of Regional Studies 28(2), 107-118.

Barkley, D. et al., 2004. "Impact of Metropolitan Regional Innovation Systems on Surrounding Nonmetro Areas," paper at the annual meetings of the Southern Regional Science Association, April.

Barry, J.M., 1997. Rising Tide. Simon and Schuster: New York.

Chatterji, M., 2004, on Fujita, Krugman and Venables’ The Spatial Economy (1999) in B. Waldorf (ed.) "Path-Breaking Books in Regional Science," Papers Reg. Sci. 83, 5989.

Florida, R., 2003. The Rise of the Creative Class: And How It's Transforming Work, Leisure, Community and Everyday Life. Basic Books: New York.

Friedman, T., 2004. "War of Ideas,” New York Times Op-Ed column, Jan. 25.

Fujita, M., P. Krugman, and A. Venables, 1999. The Spatial Economy. MIT Press: Cambridge, MA. 
Fujita, M. and J. Thisse, 2002. Economics of Agglomeration: Cities, Industrial Location, and Regional Growth. Cambridge University Press: Cambridge.

Gibbs, R., 2003. "Reconsidering the Southern Black Belt," The Review of Regional Studies 33(3), 254-263.

Glaeser, E.L. and J.E. Kohlhase, 2004. "Cities, Regions and the Decline of Transport Costs,” Papers Reg. Sci. 83, 197-228.

Hansen, N., no date, "The New Economy: Implications for Peripheral Regions," Unpublished manuscript, Department of Economics, University of Texas, Austin, nmhansen@eco.utexas.edu.

Isard W., 1956. Location and Space Economy: A General Theory Relating to Industrial Location, Market Areas, Land Use, Trade, and Urban Structure. MIT Press: Cambridge, MA. , 1975. Introduction to Regional Science. Prentice Hall.

Johnson, T., 2002. “Where is the Place in Space?” The Review of Regional Studies 32(1), 9-18.

Kilkenny M., 1998. "Transport Costs, The New Economic Geography and Rural Development," Growth and Change 29, 259-280.

Krugman, P., 1998. "Space: The Final Frontier,” The Journal of Economic Perspectives 12(2) (Spring), 161-174.

LeSage, J., 1999. "Spatial Econometrics," in S. Loveridge (ed.), The Web Book of Regional Science (www.rri.wvu.edu/regscweb.htm). Regional Research Institute, West Virginia University: Morgantown, WV.

Loveridge, S. (ed.), 1999. The Web Book of Regional Science. Regional Research Institute, West Virginia University: Morgantown, WV.

Malecki, E., 1995. "Global Cities and Back Roads: Perspectives on the Southern Economy," The Review of Regional Studies 25(3), 237-246.

Schaeffer, P., 2004. on Richardson's Regional Economics (1969) in B.Waldorf, "PathBreaking Books in Regional Science,” Papers Reg. Sci. 83, 59-89.

Washington Post. March 6, 2004, p. A12. 